\title{
Split payment and criminal fiscal law
}

\author{
Piotr OCHMAN \\ ORCID: 0000-0001-5590-3299 \\ Katedra Kryminologii i Nauk o Bezpieczeństwie \\ Uniwersytet Wrocławski
}

\section{Introductory remarks}

1. Criminal fiscal law is a distinctive branch of criminal law, generally protecting the monetary affairs of a State's Treasury, units and entities of self-government and the European Union. ${ }^{1}$ Criminal fiscal law is a branch of a sensu largo criminal law, being manifestly distinguished by a great deal of individual features ${ }^{2}$ particularly embracing:

- characteristics of the subject of protection,

- distinctiveness and separation of many material and procedural institutions,

- regulation of material, procedural, and enforcement-related issues in one comprehensive act.

The specific nature of the legally protected interest within criminal fiscal law definitely influences the philosophy of penalty in criminal fiscal law, which is slightly different compared to universal criminal law. In criminal fiscal law the enforcement of public obligations has a leading role and generally prevails over repressive measures. ${ }^{3}$

${ }^{1}$ L. Wilk, J. Zagrodnik, Prawo i proces karny skarbowy, Warszawa 2019, p. 4.

2 Z. Siwik, "Wprowadzenie," [in:] Ustawa karna skarbowa. Teksty jednolite wraz z indeksem rzeczowym i wprowadzeniem prof. dr. hab. Zygfryda Siwika, Warszawa 1999, p. XV.

${ }^{3}$ L. Wilk, J. Zagrodnik, op. cit., pp. 13-14; L. Wilk, "Zasada priorytetu egzekucji nad represją w prawie karnym skarbowym," Prokuratura i Prawo 2012, no. 7-8, p. 7; Z. Siwik, System środków penalnych w prawie karnym skarbowym, Wrocław 1986, pp. 215-312.

Nowa Kodyfikacja Prawa Karnego 53, 2019

(C) for this edition by CNS 
2. Provisions describing fiscal crimes and misdemeanours are provisions which refer to separate legal acts which regulate a desirable way of an entity's actions and their sole function is to designate applicable sanction for a violation thereof $f^{4}$ (the so-called "blank norm" - referring norm). It results from the strict relationship of criminal fiscal law with financial law. In a formal approach, this means their proper application shall require the reader to find applicable non-criminal provisions to refer to. On the other hand, in a material approach this means that the ratio of penalisation in criminal fiscal law is a violation of orders and/or prohibitions set out in financial law. In consequence, simplifying, it leads to the conclusion that the description of a crime in criminal fiscal law is the reflection of major financial law violations.

3 . The subject of the article is to present the range of criminalisation of the newly introduced provision of article $57 \mathrm{c}$ of the Criminal Fiscal Code of 9 September $1999^{5}$ penalising payment with omission of a split payment mechanism.

\section{Split payment as an instrument of prevention against tax fraud}

1. Introducing a split payment mechanism is a measure undertaken in order to counteract tax fraud and avoidance of taxation. ${ }^{6}$ As the doctrine points out, ${ }^{7}$ the common way to establish the rate of loss of budget income is the VAT Gap, ${ }^{8}$ with its significant element of losses resulting from fraud and tax extortion. The VAT Gap is defined by the Taxation and

${ }^{4}$ L. Wilk, J. Zagrodnik, op. cit., pp. 11-12.

5 Dz.U. 2018, item 1958, with further amendments, hereinafter referred to as Criminal Fiscal Code or CFC.

6 See W. Zajączkowski, "Podzielona płatność. Praktyczne aspekty nowych regulacji," Monitor Podatkowy 2018, no. 3, p. 11; A. Bartosiewicz, "Komentarz do art. 108a," [in:] A. Bartosiewicz, VAT. Komentarz, Warszawa 2019, p. 1227. See also: grounds of governmental amendment of the VAT Act and other acts project, Sejm bill no. 1864 (hereinafter referred to as Grounds I), p.1.

7 T. Michalik, "Komentarz do art. 108a ustawy o podatku od towarów i usług," [in:] T. Michalik, VAT. Komentarz, Warszawa 2019, margin number. 3.

8 Ibid. 
Customs Union Directorate-General of the European Commission as "the difference between the VAT total tax liability (VTTL), sometimes also known as VAT total theoretical liability) and the amount of VAT actually collected." According to the Final Report on the VAT Gap in the European Union, in 2016 the VAT Gap in the European Union - 28 Member States fell below EUR 150 billion and amounted to EUR 147.1 billion in nominal terms. ${ }^{10}$ The VTTL accounted for EUR 1,194.4 billion, whereas VAT revenue was EUR 1,047.3 billion. ${ }^{11}$ In relative terms, the VAT Gap share of the VTTL dropped to 12.3 percent, down from 13.2 percent in $2015 .^{12}$ It was the lowest value in the analysed period of 2012-2016. According to the Final Report on the VAT Gap in the European Union, ${ }^{13}$ the VAT Gap in Poland in 2016 was PLN 34,921 million. The VAT Gap share of the VTTL dropped to 21 percent, down from 27 percent in 2012.

2. So far, the reverse charge mechanism ${ }^{14}$ has been considered as the most effective intra-state remedy against tax abuse. The essence of the reverse charge mechanism lies in the fact that the taxable person liable for payment of tax was the purchaser of goods or services. ${ }^{15}$ In consequence, the supplier invoices the purchaser, which shall be deemed as confirmation of a purchase being subject to tax, and the tax value is to be paid by the purchaser of goods or services. The reverse charge may, however, be an easement for committing tax fraud, especially as the effect of the legislation not keeping up with fraudulent activities, which may transfer to different trade branches. ${ }^{16}$

9 Study and Reports on the VAT Gap in the EU-28 Member States: 2018 Final Report, Warszawa 2018, p. 15.

10 Ibid., p. 16.

11 Ibid.

12 Ibid.

13 Ibid., p. 43.

14 T. Michalik, op. cit.," margin number 20; M. Sęk, Odwrotne obciążenie jako mechanizm opodatkowania VAT ustug wewnatrzunijnych, Warszawa 2018, pp. 101-125.

15 See articles 199-200 of Directive of Council 2006/112/WE dated 28 November 2006, regarding the common system of VAT, OJ L 2006, No. 347, p. 1

16 M. Sęk, op. cit., pp. 101-125. The reverse charge mechanism usually gives effects in a trade branch that it applies to. Simultaneously; a phenomenon of transferring fraudulent and criminal activity is observed, which causes (1) an increase of the negative impact of tax-related abuse in other trade branches, not covered with the reverse charge mechanism and (2) appearance of new methods of tax avoidance, in particular 
3. One of the forms of tax fraud is carousel fraud, which in the Report on the use of administrative cooperation arrangements in the fight against VAT fraud is specified as:

a so-called "conduit company" (A), makes an exempt intra-community supply of goods to a "missing trader" (B) in another Member State. This company (B) acquires goods without paying VAT and subsequently makes a domestic supply to a third company (C), called the "broker." The "missing trader" collects VAT on its sales to the "broker," but does not pay the VAT to the Treasury, and disappears. The "broker" (C) claims a refund of the VAT on its purchases from B. Consequently, the financial loss to the Treasury equals the VAT paid by $\mathrm{C}$ to $\mathrm{B}$. Subsequently, Company C may declare an exempt intracommunity supply to Company (A) and, in its turn, (A) may make an exempt intracommunity supply to (B) and the fraud pattern resumes. ${ }^{17}$

It is worth pointing out that basically one of the purposes of the reversed charge mechanism is the eradication of carousel fraud. However, it turns out that in certain conditions this mechanism may also be a stimulating factor for fraud, or, used to commit fraud especially within a range of consumer goods such as mobile phones or tablets. ${ }^{18}$ These rather newer forms of tax fraud include MTIC (missing trader intra-community) and MTEC (missing trader extra-community). ${ }^{19}$ According to R.T. Ainsworth, MTIC fraud arises when "a business makes an intra-Community purchase without paying VAT, collects VAT on an onward sale, and then 'disappears' without remitting the tax." ${ }^{20}$ As MTIC fraud relies on specific to intra-Community sales of goods VAT rules and companion rules for intra-Community supplies of services, it may be committed only

trade branches affected by the reversed charge mechanism. The steel trade branch is presented as an example where introduction of the reverse charge mechanism has made carousel fraud impossible within the branch. Nevertheless, abuses have occurred in different branches, which has led to the necessity of application of the reverse charge mechanism in different branches, e.g. electronic devices - grounds of governmental amendment of VAT Act and other acts project, Sejm bill no. 3602 (hereinafter referred to as Grounds II), p. 2 .

17 Report from the Commision to the Council and the European Parliament on the Use of Administrative Cooperation Arrangements in the Fight against VAT Fraud, Brussels 2004, p. 6.

18 Grounds II, p. 3.

19 R.T. Ainsworth, VAT Fraud: MTIC \& MTEC — The Tradable Services Problem, "Boston University School of Law Working Paper" no. 10-39, 2010.

20 Ibid., p. 2. 
within the EU. MTIC fraud is most common in high-value/low-volume goods - computer chips and cell phones are the classic examples. ${ }^{21}$ In contrast to MTIC fraud, MTEC fraud arises when "a business makes an extra-jurisdictional purchase (an 'importation') of services without paying VAT, collects VAT on an onward sale of the service, and then 'disappears' without remitting the tax." 22 Therefore, MTEC fraud applies to extra-Community transactions in the field of tradable services.

4. As mentioned above, the instrument that may reduce instances of tax fraud and subsequently increase budget income is the split payment mechanism. ${ }^{23}$ It involves the following operations: the recipient of the services or the purchaser of goods splits the payment for the invoice into two parts, transferring the owed tax amount into the special bank account of the recipient/purchaser being in disposition of an applicable tax authority organ or sub-account assigned to his contractor within the tax authority system, and the net price only shall be transferred into the ordinary bank account of the contractor. ${ }^{24}$ The destination account for the owed VAT amount is dedicated exclusively for settling accounts regarding VAT, and therefore the taxable person is not entitled to dispose of the amounts allocated in this account. The split payment model has two forms: automated or manual split payment. ${ }^{25}$ In the territory of the European Union, except for the mechanism applied in Poland, there are three separate models of split payment. ${ }^{26}$

5. One of the clear benefits of the split payment mechanism taken into consideration is the fact the owed amounts of VAT are transferred into a dedicated bank account at the earliest stage when the amount of owed VAT is being calculated. ${ }^{27}$ It permits tax administration bodies to monitor and eventually block funds raised in the particular account. Nevertheless, the split payment mechanism is not completely free of defects. One

21 Ibid.

22 Ibid., p. 4.

23 W. Zajączkowski, op. cit., p. 11; A. Bartosiewicz, op. cit. See also Grounds I, p. 1.

24 T. Michalik, op. cit., margin number 36.

25 See further: Study on the Feasibility of Alternative Methods for Improving and Simplifying the Collection of VAT through the Means of Modern Technologies and/or Financial Intermediaries, Price Waterhouse Coopers 2010, p. 144.

26 T. Michalik, op. cit., margin number 42.

27 Ibid., margin number p. 63. 
of them worth highlighting is the negative impact on financial liquidity of a taxable person as well as contribution of the whole amount of owed VAT without the possibility of exclusion of input VAT amounts. ${ }^{28}$

6. The possibility of using the split payment mechanism in Poland was introduced on 1 July 2018 through the amendment of the VAT Act. ${ }^{29}$ Split payment in the light of Polish VAT regulations is a method of payment according to which the payment made by the entrepreneur shall be split into the net amount, transferred directly to the contractor's bank account, and the owed tax amount being transferred to a separate VAT bank account set up especially for this purpose. Such transfer messages carried out under the split payment mechanism shall consist of: the owed VAT amount, gross value of the transaction, identification number of VAT invoice subject to the transfer, and tax identification number of the taxable person. In order to enable every taxable person to operate within the split payment mechanism, a dedicated VAT bank account is opened by banks and other financial institutions for each entity that has already opened a personal account for the purposes of running economic activities. At first, the authorities intended the split payment mechanism to be voluntary for entrepreneurs. Nevertheless, in order to encourage taxable persons to operate within the split payment mechanism, several tax benefits were introduced, such as the non-application of additional tax liability, non-application of joint and several liability or accelerated VAT refund. ${ }^{30}$ The split payment mechanism, however, is not free of any limits. One of them is the lack of different payment methods besides bank transfers, e.g. in cash, by credit card or deductions with a different obligation towards the debtor or payment using a private account of a sole proprietor. Due to the fact the VAT Directive did not oblige taxable persons to perform payments within the split payment mechanism, introduction of the mandatory split payment in Poland required the consent of the European Commission, which thereafter had to be accepted by EU Council. By a letter registered with the European Commission on 15 May 2018, Poland requested authorisation to introduce a special measure derogating from Article 226 of the VAT Directive in order to apply a split payment mech-

28 Ibid., margin number p. 39-40.

29 Dz.U. 2018, item 62.

30 Grounds I, p. 4. 
anism for a period of three years (from 1 January 2019 to 31 December 2021). The reason for this was that ${ }^{31}$ Poland had already taken numerous measures to fight fraud (e.g. the reverse charge mechanism and joint and several liability of the supplier and the customer, the Standard Audit File, tighter rules for VAT registration and de-registration of taxable persons, increased number of audits among others) but they were insufficient to prevent VAT fraud. From Poland's point of view, in areas particularly exposed to VAT fraud (sectors of the economy such as steel, scrap, electronics, gold, non-ferrous metals, fuels, and plastics), the split payment mechanism should be introduced. According to article 1 of the Council Implementing Decision by way of derogation from Article 226 of Directive 2006/112/EC, Poland has been authorised to introduce a special statement that VAT shall be paid to the separate and blocked VAT bank account of the supplier opened in Poland on invoices issued in relation to supplies between taxable persons of goods and services listed in the Annex to this Decision where payments for supplies are made by electronic bank transfers. The Decision shall apply from 1 March 2019 to 28 February 2022. As a consequence of the above, from the date of 1 November 2019, on the grounds of amendment of VAT and other acts Act ${ }^{32}$ a partially mandatory split payment mechanism has been introduced (article 108a of the VAT Act). It concerns a situation of payment as a consideration in exchange of goods or services expressly listed in Appendix 15 to the VAT Act (e.g. tablets, notebooks, laptops, smartphones, video game consoles, digital cameras, construction work on residential buildings, concrete works, sale of parts and accessories for motorcycles) documented with a VAT invoice, amounting to a value exceeding PLN 15,000 gross or equivalent of this sum. Generally, such an invoice shall bear a note claiming expressly "split payment mechanism" (article 106e section 1 point 18 of the VAT Act). However, it is worth pointing out that the introduced obligation of procuring the payment within the split payment mechanism is not conditional upon the above-mentioned note. As a result, even if the supplier did not meet the legal requirements regarding noting the invoice

${ }^{31}$ Motives of Council Implementing Decision (EU) 2019/310 of 18 February 2019 authorising Poland to introduce a special measure derogating from Article 226 of Directive 2006/112/EC on the common system of value added tax OJ UE L 51/19.

32 Dz.U. 2019, item 1751. 
properly, the buyer is legally bound to process the payment for goods and services set out in Appendix 15 within the split payment mechanism. The buyer therefore shall be aware of the subject of a transaction, as he is the party to initiate payment and remains liable for choice of payment form. The buyer is obliged to verify whether the goods purchased or services received are indicated in Appendix 15 and shall be aware of any obligations resulting from such a transaction. ${ }^{33}$

\section{Criminal fiscal consequences of payment with omission of the split payment mechanism}

1. In relation to the introduced amendments regarding application of split payment, the Criminal Fiscal Code has been enriched with article 57c CFC which penalises procuring the payment with omission of the split payment mechanism. The offence described in article $57 \mathrm{~b}$ CFC can be qualified as a fiscal crime (article 57c $\S 1 \mathrm{CFC}$ ), whereas in "minor occurrences" also can be qualified as a fiscal misdemeanour (article 57c $\S 2$ CFC). This kind of regulation may be deemed as a manifestation of an elastic crime policy.

2. The provision of article 57c CFC protects the monetary affairs of the State Treasury by countering abuses related to avoidance of payment of VAT. ${ }^{34}$ Provision of article $57 \mathrm{c}$ CFC is a fiscal-criminal instrument of securing the application of a mandatory split payment mechanism, as set out in article 108a section 1a of the VAT Act.

3. The mentioned offences are of an individual nature and are committable by a taxable person ${ }^{35}$ — a natural person legally bound with a tax obligation by particular tax general acts. ${ }^{36}$ In accordance with the provision of article $9 \S 3 \mathrm{CFC}$, a person who on the basis of any of the following: (1) provision of law or, (2) administrative decision of authorities, or (3) a contract or (4) due to actual actions; handles economic issues, especially financial issues, of a natural or legal person or any other entity

33 See for example article $96 \mathrm{~b}$ CFC.

34 See G. Skowronek, Kodeks karny skarbowy. Komentarz, Warszawa 2020, p. 179 $57 \mathrm{c}$, margin number 3 .

35 See ibid., pp. 178-179.

36 See article $53 \S 30$ CFC. 
that underlies tax obligations according to tax legislation, shall bear alike criminal liability as a perpetrator for violation of article 57c CFC.

4. The essence of offences described in article $57 \mathrm{c}$ CFC is a violation of an obligation to process payment arising from a VAT invoice within the split payment mechanism, whenever this shall be mandatory. As indicated previously, this obligation is expressly set out in article 108a of the VAT Act and regards a situation of payment for goods or services mentioned in Appendix 15 to the VAT Act documented with a VAT invoice, when the amount due resulting from the invoices exceeds PLN 15,000 gross or equivalent of this sum. Omission of payment within the split payment mechanism for services or goods mentioned in Appendix 15 to VAT documented with a VAT invoice of a value lower than PLN 15,000 is not penalised. Due to the fact that the obligation of payment in the split payment mechanism concerns amounts resulting from purchases of goods or services set out in Appendix 15, the obligation of performance of the split payment mechanism concerns only these amounts indicated on the invoice, which relate to goods and services as per Appendix 15, excluding positions of the invoice which include goods and services not set out in Appendix 15. As a consequence, omission of payment within the split payment mechanism regarding the above-mentioned goods and services not mentioned in Appendix 15 is not a criminal offence. Under the provisions of article 57c CFC, only payment with omission of the split payment mechanism is penalised. And yet, if the contractor serves the purchaser with the bank account number not suitable for service of the split payment mechanism this conduct shall not be qualified as an offence against article 57c CFC. Although the situation of the purchaser regarding criminal fiscal liability is slightly different - before ordering the payment within the split payment mechanism he is obliged to verify whether the receiver of payment (contractor, seller) and his VAT account number are on the so-called "white

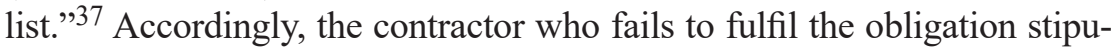
lated in article 106e section 1 point 18 of the VAT Act - the obligation to note the VAT invoice with words "split payment mechanism" - shall not be penalised under article 57c CFC. However, in both these cases article $62 \S 1$ or 5 CFC (faulty issuance of VAT invoice) may be applied. It also shall be found important that lack of a note entitled "split payment mech-

37 See article $96 \mathrm{~b}$ CFC.

Nowa Kodyfikacja Prawa Karnego 53, 2019

(C) for this edition by CNS 
anism" on the invoice does not entitle a taxable person to omit to perform this payment mechanism regarding cases when split payment is mandatory under article 108a of the VAT Act. The following conduct shall also not be penalised under article 57c CFC: deduction processed on the grounds of article 498 of the Civil Code (article 108a section 1d of the VAT Act), payment of amounts resulting from invoice documenting transaction performing the consideration related with PPP (public-private partnership), ${ }^{38}$ provided that the entity receiving the payment, as for the day of the payment being processed, was a private partner, with whom the public entity entered into a PPP agreement with, or a sole company of private partner, or a company whose sole shareholders are private partners, whose public entity has concluded a PPP agreement with.

5. Offences described in article $57 \mathrm{c}$ CFCe may only be committed in the form of direct intention or conceivable intent.

6 . Depending on whether the actions of the perpetrator shall be qualified as a criminal offence or misdemeanour, the possible penalty shall differ. In a case where omission of procuring the split payment mechanism is deemed to be a criminal offence (article 57c $\S 1$ CFC) the perpetrator is punishable with a fine of $10-720$ daily income rates. The daily income rate cannot be lower than $1 / 30$ th of the minimal remuneration for labour, nor exceed its multiplication by 400 . As far as a fiscal misdemeanour from article 57c $\S 1 \mathrm{CFC}$ is concerned, the fine shall be calculated within the boundaries of a minimal 1/10th of minimal remuneration for labour up to its multiplication by 20 .

\section{Summary}

The introduced criminal fiscal regulation, because of its "blank" (referring) characteristics, comprises a reassurance measure of the financial-law order of performing payments within the split payment mechanism. Besides the existence of tax-law sanctions whose application is conditional upon violation of the above-mentioned order, the introduced criminal fiscal law solution is an additional instrument deterring potential

38 As mentioned in article 7 section 1 of PPP Act dated 19 December 2008 (Dz.U. 2019, No. 1445, item 1572). 
tax abusers from tax avoidance. Problems connected with the application of amended norms regarding split payment will show to what extent this amended regulation shall apply in practice.

\section{References}

Ainsworth R.T., VAT Fraud: MTIC \& MTEC - The Tradable Services Problem, "Boston University School of Law Working Paper" no. 10-39, 2010.

Bartosiewicz A., VAT. Komentarz, Warszawa 2019.

Grounds of governmental amendment of VAT Act and other acts project, Sejm bill no. 1864. Grounds of governmental amendment of VAT Act and other acts project, Sejm bill no. 3602. Michalik T., VAT. Komentarz, Warszawa 2019.

Report from the Commision to the Council and the European Parliament on the Use of Administrative Cooperation Arrangements in the Fight against VAT Fraud, Brussels 2004.

Sęk M., Odwrotne obciażenie jako mechanizm opodatkowania VAT ustug wewnątrzunijnych, Warszawa 2018.

Siwik Z., System środków penalnych w prawie karnym skarbowym, Wrocław 1986.

Siwik Z., "Wprowadzenie," [in:] Ustawa karna skarbowa. Teksty jednolite wraz z indeksem rzeczowym i wprowadzeniem prof. dr. hab. Zygfryda Siwika, Warszawa 1999.

Skowronek G., Kodeks karny skarbowy. Komentarz, Warszawa 2020.

Study and Reports on the VAT Gap in the EU-28 Member States: 2018 Final Report, Warszawa 2018.

Study on the Feasibility of Alternative Methods for Improving and Simplifying the Collection of VAT through the means of Modern Technologies and/or Financial Intermediaries, Price Waterhouse Coopers 2010.

Wilk L., "Zasada priorytetu egzekucji nad represją w prawie karnym skarbowym," Prokuratura i Prawo 2012, no. 7-8.

Wilk L., Zagrodnik J., Prawo i proces karny skarbowy, Warszawa 2019.

Zajączkowski W., "Podzielona płatność. Praktyczne aspekty nowych regulacji," Monitor Podatkowy 2018, no. 3.

\section{Summary}

The purpose of the article is to present solutions in Polish criminal fiscal law aimed at protecting the mandatory use of the split payment mechanism. The analysis is preceded by a brief overview of instruments aimed at counteracting tax fraud as well as the effects of tax fraud. The main element of the article are considerations regarding article $57 \mathrm{c}$ of the Criminal Fiscal Code penalising making payments without using the split payment mechanism.

Keywords: criminal fiscal law, tax offence, split payment, tax fraud. 